\title{
Atminties institucijų standartizacinè integracija: nacionalinis lygmuo
}

\author{
Nijolè BLIŪDŽIUVIENÉ \\ Lietuvos nacionaliné Martyno Mažwydo biblioteka, Vilnius, el. p. n.bliudziuviene@inb.lt
}

Straipsnyje analizuojama Lietuvos standartizacijos departamento technikos komiteto LST TK 47 „Informacija ir dokumentavimas" veikla ir pletra atminties institucijy kultuirinès ir standartizacinès integracijos procese.

Reikšminiai žodžiai: standartizacija; standartizaciné integracija; Lietuvos standartas; tarptautinis standartas; atminties institucija; technikos komitetas; bibliografijos tarnyba; tarptautinès standartinès numeravimo sistemos.

\section{Ivadas}

Biblioteku, archyvy ir muzieju bendradarbiavimą skatina šiuolaikinis socialinio, kultūrinio ir ekonominio gyvenimo kontekstas, augantis visuomenès poreikis informacijai, sparti ir dinamiška technologijụ kaita. Tuo tarpu strateginé atminties institucijų inovacija išryškèja kuriant virtualią kultūros paveldo informacinę sistemą. Todèl kultūriné integracija kaip didelio kultūros paveldo išteklių masyvo jungimas i bendrą informacinę struktūrą praktiniu lygmeniu pasireiškia ịvairių kultüros subjektų, tarp kurių - ir atminties institucijos, veiklos krypčiu, formų, metodụ sąveika.

Kultūrinès integracijos procese dalyvaujančiụ instituciju, kurios formuoja, integruoja ir skleidžia žmonijos kultürqu, užfiksuotą kultūros paveldo objektuose', standartizacijos poreikis gali igauti standartizacinès integracijos formą. Atminties institucijų standartizacinè integracija - suartėjimo ir sąveikos procesas, kuri lemia šiy institucijų dalyvavimas standartizacijos veikloje ir virtualios kultūros paveldo informacinès sistemos kūrimas. Standartizacinè integracija suteikia galimybę dalyvauti standartizacijos veikloje ir, išlaikant subjektų savarankiškumą, sujungti žinias, gebejjimus ir kitus žmogiškuosius bei materialius išteklius j visumą. Dalyvavimas technikos komiteto LST TK 47 "Informacija ir dokumentavimas" (toliau - LST TK 47 "Informacija ir dokumentavimas") veikloje - viena iš galimų atminties instituciju partnerystès ir integracijos formụ.

\section{LST TK 47 ,Informacija ir dokumentavimas" veiklos pradžia}

1997 m. pabaigoje Lietuvos standartizacijos departamentas prie Lietuvos Respublikos aplinkos ministerijos, kurdamas ir tobulindamas standartizacijos sistema, pakeite standartỵ projektų rengimo ir standarty tvirtinimo tvarkq ${ }^{2}$. Remiantis nacionalinès standartizacijos darbų organizavimo tvarka, standartams rengti turèjo būti sudaromas atitinkamos standartizacijos srities technikos komitetas, kuriame atstovaujamı instituciju igaliotieji atstovai sprendimus priima bendru sutarimu.

Vienas pagrindinių Lietuvos standartizacijos principu - pirmenybès teikimas tarptautinei ir Europos standartizacijai. Tuo tikslu buvo nustatyta tarptautiniy ir Europos standartu priemimo Lietuvos standartais tvarka, o technikos komitetas tapo vienu svarbiausiy standartizacijos veiklos kolektyviniu subjektu, kuriame atliekami pagrindiniai standartizacijos procesai.

Nuoseklus bei sistemingas požiūris i pagrindinius standartizacijos principus ir tikslus padejo sukurti informacijos ir dokumentavimo standartizavimo srities sistemos gaires Lietuvoje. $1998 \mathrm{~m}$. pabaigoje Lietuvos standartizacijos departamentas prie Lietuvos Respublikos aplinkos ministerijos kreipèsi i Lietuvos nacionalinès Martyno Mažvydo bibliotekos Bibliografijos ir knygotyros centrą (toliau - Bibliografijos ir knygotyros centras), kaip j instituciją, daugiausia nuveikusią taikant tarptautinius standartus Lietuvoje, skatindamas nuostatą šiuos standartus diegti plačiau. 
XX a. 10-ojo dešimtmečio pradžioje buvo ịkurti Bibliografijos ir knygotyros centro padaliniai - nacionalinés ISSN, ISBN ir ISMN agentūros. Bibliografijos ir knygotyros centro iniciatyva $1994 \mathrm{~m}$. vertimo būdu buvo parengtas tarptautinio standartinio knygos numerio (ISBN), - $1998 \mathrm{~m}$. - tarptautinio standartinio muzikos leidinio numeris (ISMN) Lietuvos standartas. Taigi dar iki oficialaus LST TK 47 ịsteigimo minètame Nacionalinés bibliotekos padalinyje jau buvo taikomi pirmieji tarptautiniai standartai, susiję su tarptautine standartine numeravimo sistema, skirta teikti knyginés produkcijos, muzikos leidiniy ir serialinių leidiniụ identifikavimo kodus.

1998 m. lapkričio 11 d. LST TK 47 steigiamajame susirinkime dalyvavo du Lietuvos nacionalinės Martyno Mažvydo bibliotekos atstovai, po vieną atstovą iš Lietuvos medicinos, Lietuvos mokslų akademijos (dabar - Lietuvos moksly akademijos Vrublevskių biblioteka), Lietuvos technikos biblioteky, Lietuvos Respublikos kultūros ministerijos ir Vilniaus universiteto Komunikacijos fakulteto ${ }^{3}$. LST TK 47 ketinta pavadinti „Bibliotekininkysté ir bibliografija"; toks pavadinimas jvardijo standartizuotinas veiklos sritis ir pasirinkimą tapti atitiktiniu ISO/ TC 46/SC9 komitetu. Kita vertus, tai rodẻ suinteresuoty igaliotujų atstovų profesinès veiklos kryptị bei institucinę priklausomybę. Penki ekspertai atstovavo bibliotekoms, vienas iki $2001 \mathrm{~m}$. - Vilniaus universitetui.

Siekiant užtikrinti vieningq standartizacijos politika bibliotekininkystès srityje $1998 \mathrm{~m}$. gruodžio $31 \mathrm{~d}$. Lietuvos standartizacijos departamento prie Lietuvos Respublikos aplinkos ministerijos direktoriaus jsakymu buvo sudarytas naujas technikos komitetas, kurio veiklos sritis apèmè bibliotekininkystę ir bibliografiją. LST TK 47 „Bibliotekininkystė" nuostatuose numatyla veikla leido technikos komiteto atstovams nekliudomai propaguoti komiteto tikslus ir uz̃davinitus bei dalyvauti tarptantiniy ir Europos standartizacijos organizacijy, kuriu nariu yra ir Departamentas, atitinkanciiy ju technikos komitety sriti, veikloje - rengiant tarptautinius ir Etropos standartus ${ }^{5}$. Nuostatuose buvo numatyta, kad technikos komiteto buveine ir metodinis standartizacijos centras yra Bibliografijos ir knygotyros centras.

Taigi technikos komitetas tapo vienintelis subjektas Lietuvoje, atsakingas už bibliotekininkystès ir bibliografijos standartizacijos veiklą, galintis teikti pasiülymus del tarptautiniy ir Europos standarty priemimo Lietuvos standartais bibliotekininkystes ir bibliografijos srityje. Taip pat technikos komitetas galéjo ir oficialiai dalyvauti tiek tarptautineje, tiek Europos tam tikros srities standartizacijos veikloje bei teikti informacijq nustatyta tvarka komiteto nariams ir suinteresuotoms organizacijoms ${ }^{6}$.

Tarptautinès standartizacijos organizacijos technikos komiteto ISO TC 46 pakomitečio SC 9 „Identification and Description" veikla tuo metu buvo laikytina pagrin- dine LST TK 47 standartizacijos sritimi. Toki pasirinkimą pirmiausia lémè tai, kad šiame pakomitetyje buvo daugiausia parengty standartu, tuo metu labiausiai reikalingụ bibliografijos tarnyboms ir kuriamai Lietuvos integralios biblioteky informacijos sistemai. Kita vertus, LST TK 47 "Bibliotekininkysté" veikloje dalyvavo tik penkių didžiujų Lietuvos biblioteku igaliotieji atstovai, kurie standartizacijos veikloje reiškẻ juos igaliojusios institucijos nuomonę.

Lietuvos standartizacijos departamentas prie Lietuvos Respublikos aplinkos ministerijos $2002 \mathrm{~m}$. sausio mèn. LST TK 47 „Bibliotekininkystè " prašymu kreipési i Tarptautinę standartizacijos organizaciją dẻl narystès stebétojo teisèmis technikos komitete ISO/TC 46 „Information and Documentation" ir keturiuose jo pakomitečiuose?. Po ménesio iš Tarptautinés standartizacijos organizacijos Centrinio sekretoriato buvo gautas patvirtinimas dèl narystés ${ }^{8}$. Lietuvos standartizacijos departamento nustatyta tvarka LST TK 47 pradejo bendradarbiauti tarptautiniu lygmeniu ir tapo atitiktiniu ISO/TC 46 ,Information and Documentation" technikos komitetu.

LST TK 47 „Bibliotekininkystė“" nariu stebétoju buvo patvirtintas visuose keturiuose Tarptautinès standartizacijos organizacijos technikos komiteto TC 46 ,Information and Documentation" pakomitečiuose - ISO TC 46/SC 4 "Computer Applications in Information and Documentation (dabar „Technical Interoperability ${ }^{4}$ ), ISO TC 46/SC 8 „Quality - Statistics and Performance Evaluation", ISO TC 46/SC 9 „Identification and Description“, ISO TC 46/ SC 11 ,Archives/records Management ${ }^{\text {t" }}$

2003 m. gegužẻs mėnesị Romoje Tarptautinès standartizacijos organizacijos surengtame technikos komiteto ISO/TC 46 ,Information and Documentation“ metiniame susitikime pirmą karta dalyvavo Lietuvos atstovai. ISO/TC 46 "Information and Documentation" buvo ikurtas $1947 \mathrm{~m}$, tad Lietuva tuo metu neturèjo galimybès dalyvauti jame ir siusti savo atstovus. LST TK 47 "Bibliotekininkystéc pirmininkès ataskaitoje, teiktoje Lietuvos standartizacijos departamentui, pabréžiami trys pagrindiniai dalyvavimo tarptautinio lygmens susitikime aspektai, reikšmingi tiek Lietuvos atminties institucijų integracijai šalies mastu, tiek ju integracijai i Tarptautinès standartizacijos organizacijos veikla. Visy pirma ši patirtis buvo naudinga susipažinti su ISO organizacine-funkcine struktūra ir jos veiklos strategija, oficialus atstovavimas sudarè galimybę susipažinti su atskiru ISO/TC 46 darbo grupiy bei pakomitečity vykdoma veikla bei rengiamais standartais, taip pat buvo užmegzti nauji profesiniai ryšiai bei numatyta, kaip tobulinti LST TK 47 veikla ${ }^{9}$.

$2003 \mathrm{~m}$. birželio mèn. buvo priimtas sprendimas iš esmès pertvarkyti technikos komiteto TK 47 „Bibliotekininkysté“" organizacinę struktūrą, itraukti naujus narius 
ir priimti jų igaliotuosius atstovus bei papildyti technikos komiteto turinị naujomis standartizacijos sritimis. Lietuvos standartizacijos departamento direktorius pritaré tokiai pertvarkai, nepaisant to, kad prioritetas skiriamas Europos standartams. Buvo pabrèžta, kad LST TK 47 „Bibliotekininkystè‘ neturi atitiktinio CEN komiteto, todel jo veikla remiasi ISO/TC 46 technikos komiteto standartizacijos sritimis bei jo parengtais standartais, taikomais bibliotekininkystès ir informacijos veikloje ${ }^{10}$.

Bibliotekos pirmiausia siekẻ įvesti tvarką valstybinès bibliografinès apskaitos, spaudos ir biblioteku statistikos bei su šia veikla susijusios leidybos srityse, todèl, atsižvelgiant i LST TK 47 ,Bibliotekininkystèc nariy poreikius, Lietuvos standartais daugiausia buvo perimta ISO/TC 46/ SC 9 parengtų standarty. Kuriant Lietuvos integralią bibliotekų informacijos sistemą buvo remtasi ISO/TC 46/SC 4 parengtais standartais, skirtais sistem 4 funkciniam suderinamumui užtikrinti, juos taikant tiesiogiai, neperèmus Lietuvos standartais. Tačiau kitų ISO/TC 46 ,Information and Documentation" pakomitečiy parengti informacijos ir dokumentavimo tarptautiniai standartai nebuvo perimami Lietuvos standartais dẻl to, kad kitos atminties institucijos, išskyrus bibliotekas, nedalyvavo nacionalinèje standartizacijos veikloje ir neturejo galimybiy tai padaryti.

Kai LST TK 47 ,Bibliotekininkystë" tapo atitiktiniu ISO/TC 46 ,Information and Documentation" technikos komitetu ir visų jo pakomitečių nariu stebėtoju, atsirado galimybė ir būtinybè sudaryti sąlygas standartizacijos veikloje dalyvauti visoms atminties institucijoms ir kitoms organizacijoms, suinteresuotoms informacijos ir dokumentavimo standartizacijos veikla. Pradéta pertvarkyti organizacinę LST TK 47 „Bibliotekininkystè" struktūrą, suteikiant technikos komitetui naujo turinio, atsižvelgiant i dalyvaujančiy organizaciju standartizacijos reikmes.

$2003 \mathrm{~m}$. sudaryto technikos komiteto LST TK 47 pakomitečio PK 1 ,Informacinis ir lingvistinis aprūpinimas" sudètị ir turinị lèmè ISO/TC 46 ketvirtojo, šeštojo ir devintojo pakomitečių SC 4, SC 8 ir SC 9 standartizuojamu sričių specifika bei ISO/TC 46 sekretoriato rengiamų standarty standartizacijos objektai. LST TK 47 antrajam pakomitečiui PK 2 ,Archyvu/dokumentu vadyba“ buvo priskirta ISO/TC 46/SC 11 standartizacijos sritis, susijusi su dokumentu valdymu archyvuose ir iš dalies - ISO/ TC 46/SC 4 veiklos sritis, susijusi su informacinių sistemų funkciniu suderinamumu.

2003-2004 m. technikos komiteto veiklos dokumenty analizé rodo, kad LST TK 47 ,Informacija ir dokumenta-

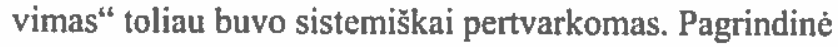
to meto permainų ir plètros kryptis - nauju institucijų, siekiančiı̨ dalyvauti standartizacijos veikloje, jtraukimas i technikos komitetą. Buvo tvirtinami komiteto nariu ir ju atstovy igaliojimai, svarstomas nuostaty projektas ${ }^{11}$, kuris vèliau priimtas LST TK 47 veiklos pagrindu ${ }^{12} .2003 \mathrm{~m}$.
LST TK 47 "Informacija ir dokumentavimas" naujais nariais buvo patvirtintos valstybès, mokslo institucijos ir privati imonè, dirbanti Lietuvos informaciniu sistemų ir programinès jirangos kūrimo srityje.

$2004 \mathrm{~m}$. i technikos komiteto veiklą jsitraukẻ Lietuvos muziejai. Sukurtam naujam technikos komiteto pakomitečiui LST TK 47 PK 3 „Muziejai“" buvo pavesta atsakomybẻ už muzieju veiklos standartizavimą ir Lietuvos standartụ projektų rengimą. Nors patys muziejų igaliotieji atstovai pastebejo, kad ISO standarty muziejams beveik néra, tačiau dalyvavimas LST TK 47 ,Informacija ir dokumentavimas" veikloje suteikè galimybę rengti originalių nacionalinių standartu projektus arba Amerikos ar kity saliy standartus jorminti kaip nacionalinius, kai nèra atitinkamu tarptautiniy ar Europos standarty ${ }^{13}$.

Lietuvos standartizacijos departamentas prie Lietuvos Respublikos aplinkos ministerijos, siekdamas užtikrinti nuoseklią standartizacijos veiklą informacijos ir dokumentavimo srityje ir jvertindamas beveik pusantry metų vykusią LST TK 47 pertvarką ir plètrą, $2004 \mathrm{~m}$. kovą iteisino technikos komiteto igaliotujy atstovy susirinkimo protokoly nutarimus. Lietuvos standartizacijos departamento direktoriaus jsakymu LST TK 47 pavadinimas „Bibliotekininkyste“ buvo pakeistas i LST TK 47 "Informacija ir dokumentavimas", patvirtinti nauji technikos komiteto nuostatai. Praplèsta LST TK 47 veiklos sritis ivardyta kaip veiklos, susijusios su bibliotekomis, dokumentavimo ir informacijos centrais, bibliografavimo ir referavimo tarnybomis, archyvy ir dokumenty vadyba, informacijos mokslu ir leidyba, standartizacija ir nustatyta, kad ji atitinka Tarptautines standartizacijos organizacijos (ISO) technikos komiteto ISO/TC 46 ,Information and Documentation" veiklos sriti ${ }^{14}$.

Atnaujinto ir pertvarkyto LST TK 47 ,Informacija ir dokumentavimas"s sekretoriatu Lietuvos standartizacijos departamento jisakymu ir technikos komiteto nuostatais patvirtintas Lietuvos nacionalinès Martyno Mažvydo bibliotekos Bibliografijos ir knygotyros centras. Nuostatuose numatyta, kad kiekviena suinteresuota institucija, kurios veikla susijusi su LST TK 47 "Informacija ir dokumentavimas" veiklos sritimi, gali tapti komiteto nare bei dalyvauti jo veikloje, siülyti jrašytinus $i$ jos standarty programq darbus ${ }^{15}$. Taigi technikos komiteto veiklos pertvarka buvo vykdoma atsižvelgiant $j$ vis labiau europiniu ir pasauliniu mastu pastebimą atminties ir kitu institucijy kultūrinès integracijos tendenciją, kurios viena sąlygu standartizacinè integracija.

Savanoriškas dalyvavimas ir atvira galimybè dalyvauti LST TK 47 ,Informacija ir dokumentavimas“ veikloje bei didejjantis standartų poreikis pavienèse ịvairaus informacijos ir dokumentavimo profilio įstaigose ir bendroje institucijų kultūros paveldo skaitmeninimo, išsaugojimo, sklaidos ir prieigos veikloje lèmé naujụ suinteresuoty 
nariy jsitraukima i technikos komiteto veiklą. 2006$2007 \mathrm{~m}$. j technikos komitetą LST TK 47 „Informacija ir dokumentavimas" savo igaliotuosius atstovus delegavo valstybẻs archyvas, vykdomosios valdžios institucija, visuomeninis transliuotojas ir šalies kino rinkoje veikianti privati imoné ${ }^{16}$. Sie duomenys leidžia teigti, kad standartizacijos poreikis augo ne tik popierinius dokumentinius išteklius turinčiose, bet ir kaupiančiose garso bei vaizdo medžiaga ir teikiančiose prie jos prieiga istaigose.

Tokiais ištekliais disponuojančiu istaigu susidomėjimas standartizacija ir konkrečių standarty poreikis pastebimas ne tik nacionalinèje, bet ir tarptautinèje, ypač - Europos lygmens standartizacijos veikloje. $2005 \mathrm{~m}$. Europos lygmeniu buvo pradètas darbas, siekiant suderinti kinematografijos darbu katalogavimo ir indeksavimo praktikas. Tokiu tikslu buvo sudaryta Europos standartizacijos komiteto Techninės tarybos tiksliné darbo grupé CEN/BT/TF 179 „Cinematographic Works" (dabar CEN/ TC 372), siekianti parengti du Europos standarty projektus, susijusius su kinematografijos darbu metaduomenimis ir filmų identifikavimu, apimančiu bendrąsias katalogavimo ir indeksavimo taisykles.

Pagal nuostatuose patvirtinta veiklos sriti technikos komitetas LST TK 47 "Informacija ir dokumentavimas" sické aktyviau dalyvauti Europos standartizacijos komiteto Techninès tarybos tikslinès darbo grupès veikloje. $2007 \mathrm{~m}$. šs komitetas sudare naują pakomitetj „Kinematografijos kūriniai“"17? Nuo $2004 \mathrm{~m}$. Lietuvos standartizacijos departamentas prie Lietuvos Respublikos aplinkos ministerijos yra Europos standartizacijos komiteto narys, todè nacionalinio technikos komiteto igaliotieji atstovai dalyvavo rengiant Europos standartu projektus.

Lietuvos nacionaliniam audiovizualiniam paveldui kataloguoti ir indeksuoti niekada nebuvo naudojami kokie nors būtent kinematografiniams kūriniams skirti Europos standartai. LST TK 47 ,Informacija ir dokumentavimas“ pakomitečio „Kinematografijos kūriniai“" ekspertai turèjo galimybę dalyvauti rengiant Europos standarty projektus. Valerijos Jusevičiūtès teigimu, tokia veikla padèjo Lietuvai integruotis ị Europos Sajungos audiovizualinio paveldo informacinę erdvę, palengvino vidaus ir tarptautinę veiklą audiovizualinio paveldo kaupimo, tvarkymo, išsaugojimo ir naudojimo srityse ${ }^{\mathrm{l}}$.

$2008 \mathrm{~m}$. LST TK 47 „Informacija ir dokumentavimas" ir Lietuvos standartizacijos departamento pastangomis Vilniuje surengtas Europos standartizacijos komiteto CEN/TC 372 susitikimas, kuriame buvo svarstomi kinematografijos küriniy metaduomenụ ir filmų identifikavimo standarty projektai. 2009-2010 m. Europos standartizacijos komitetas patvirtino Europos standartus, kuric apibrèžia kinematografijos kūrinių metaduomenụ terminiją, metaduomenų funkcinio suderinamumo elementy rinkinius ir sandara. Abu Europos standartai technikos komiteto LST TK 47 „Informacija ir dokumentavimas teikimu perimti Lietuvos standartais.

LST TK 47 ,Informacija ir dokumentavimas“, kasmet rengdamas Lietuvos standartizacijos departamento tvirtinamą standarty programą, ísipareigoja parengti standarty projektus, kuriuos Lietuvos standartais tvirtina departamentas. $2012 \mathrm{~m}$. pradžios duomenimis, yra 53 galiojantys informacijos ir dokumentavimo srities standartai ${ }^{19}$. Lietuvos standartais perimta daugiau kajp pusė visų ISO/TC 46 sekretoriato ir keturiy jo pakomitečiu parengtụ standarty.

Atminties ir kitos institucijos, jžvelgdamos standartizacijos būtinybę ir teikiamą naudą, savanoriškai prisideda prie technikos komiteto veiklos. LST TK 47 ,Informacija ir dokumentavimas" darbe dalyvauja 19 nariu, tarp kuriy yra bibliotekos, archyvai, muziejai, taip pat valstybès, mokslo institucijos ir privačios imonès bei 23 igaliotieji atstovai ${ }^{20}$, atstovaujantys minétiems nariams.

Taigi technikos komitetas buvo kurtas nuosekliai, atsakingai ir įžalgiai, numatant galimą plétros perspektyvą. Bibliotekos pirmosios ịsitraukè ị pagal tarptautinio ir europinio lygmens standartizacijos principus organizuojamą nacionalinę standartizacijos veiklą, plẻsdamos paslaugu spektrą, bendradarbiaudamos su šalies it užsienio institucijomis, siekdamos integruoti savo išteklius j curopines ar pasaulines kultūros ištekliụ duomenụ bazes. Pamažı i nacionalinę standartizacijos veiklą ịsitraukẻ kiti informacijos ir dokumentavimo sektoriai, suvokdami standarty taikymo svarbą ir standartizacijos veiklos reikšmę.

Daugiapakope technikos komiteto LST TK 47 pertvarka parodè, kad standartizacijos komiteto nariai ir ju igaliotieji atstovai, siekdami realizuoti atstovaujamos jstaigos standarty poreiki bei jitvirtinti tarpsektorinés integracijos pamatą, aktyviai domejosi standartizacijos veikla, galimybèmis i ja jsitraukti bei taikyti būtinas priemones. Atminties institucijos atsiliepé $\mathfrak{j}$ rinkos poreikị teikti paslaugas, naudojantis šiuolaikiniy technologijy teikiamomis galimybèmis, prisidèti prie informacinès ir žiniụ visuomenẻs kūrimo infrastruktūros.

Apibendrinant galima teigti, kad kryptingai pertvarkius technikos komiteta LST TK 47 „Informacija ir dokumentavimas", suburta stipri kompelentingy eksperty grupé, kuri gali atstovauti Lietuvai Tarptautinèje standartizacijos organizacijoje ir Europos standartizacijos komitete, teikti pastabas bei pasiülymus rengiant standartu projektus, konsultuoti standartizacijos klausimais besidominčius asmenis ir propaguoti standartizacijos veikla. Technikos komitetas, vienijantis bibliotekц, muziejų, archyvu ir kitu suinteresuotų instituciju atstovus, gali būti laikomas perspektyvia tarpsektorinès partnerystès forma ir svarbiu standartizacijos veiklos subjektu, gebančiu labiau pažinti standartu jvairovę, standartizacijos veiklos specifiką, pritaikyti žinias atminties institucijų kultūrinés ir standartizacinès integracijos procesuose. 
' Lietuvos kultūros paveldo skajtmeninimo, skaitmeninjo furinio saugojimo ir prieigos strategija : patvirtinta Lietuvos Respublikos Vyriausybès $2009 \mathrm{~m}$. gegužès 20 d. nutarimu Nr. 493 // Valstybès Żinios. - 2009, Nr. 66-2624.

${ }^{2}$ Dèl standartizacijos darby organizavimo tvarkos : Lietuvos standartizacijos departamento direktoriaus $1997 \mathrm{~m}$. gnoodzio $30 \mathrm{~d}$. jsakymas Nr, 355 // Valstybès żinios. - 1998, Nr. 1-37.

' Lietuvos standartizacijos departamento technikos komiteto „Bibliotekininkystè ir bibliografija“ steigiamasis susirinkimas. Protokolas [mašinraštis]. Vilnius, 1998, Lietuvos standartizacijos departamentas prie Lietuvos Respublikos aplinkos ministertjos. Ap. 1, b. 285, lap. 35.

“ Dél Lietuvos standartizacijos departamento technikos komiteto „Bibliotekininkystè sudarymo. Lictuvos standartizacijos departamento prie Lietuvos Respublikos aplinkos ministerijos direktoriaus jsakymas Nr. 97, 1998 m. gruodžio 31 d. [mašinraštis]. Vilnius, 1998, lap. 3.

"Lietuvos standartizacijos departamento technikos komiteto „Biblsotekininkysté ir bibliografijaat steigiamasis susirinkimas..., lap. 2.

Ten pat, lap. 3.

${ }^{7}$ O-Membership in ISO/TC 46 and ISO Technical Committee ISO/TC $46 / \mathrm{SCs} 4,8,9,11$. Lithuanian Standards Board under the Ministry of Environment of the Republic of Lithuania. Lietuvos standartizacijos departamento prie Lietuvos Respublikos aplinkos ministerijos direktoriaus raštas Nr. 31-05-83, $2002 \mathrm{~m}$. sausio $6 \mathrm{~d}$. [maštnraštis]. Vilnius, 2002, p. 1 .

"Zaceh, Linda, ISO/TC 46 and SCs - LST O-membership. Pranešimas Liefuvos standartizacijos departamento direktoriui, $2002 \mathrm{~m}$. vasario 6 d. [maŠinraకtis]. Vilnius, 2002, p. 1.

"Varniené, Regina. LST TK 47 „Bibliotekininkystẹ" pirmininkés dalyvavimo ISO TC 46 pakomitečị susirinkimuose, jvykusiuose Romoje 2003 m. gegužes 19-23 d. atıskaita [mašinraštis]. Vilnius, 2003, p. 4,

${ }^{10}$ Lietuvos standartizacijos departamento technikos komiteto LST TK 47 "Bibliotekininkystè" susirinkimo protokolas Nr. 3, $2003 \mathrm{~m}$. birželio $25 \mathrm{~d}$. [mašinraštis]. Vilaius, 2003. Lietuvos standartizacijos departamentas prie Lietuvos Respublikos aplinkos ministerijos. Ap. 1, b. 296, lap. 16.

"Lietuvos standartizacijos departamento technikos komiteto LST TK 47 "Informacija ir dokumentavimas" susirinkimo protokolas Nr. 4, 2003 m. liepos 4 d. [masinraštis]. Vilnius, 2003. Lietuvos standartizacijos dcpartamentas prie Lictuvos Respublikos aplinkos ministerijos. Ap. 1, b. 296, lap. 42.

${ }^{12}$ Lietuvos standartizacijos departamento technikos komiteto LST TK 47 "Informacija ir dokumentavimas" susirinkimo protokolas $\mathrm{Nr} .5$, $2003 \mathrm{~m}$. spalio mèn. $21 \mathrm{~d}$. [mašinraštis]. Vilnius, 2003. Lietuvos standarizacijos departamentas prie Lietuvos Respublikos aplinkos ministerijos. Ap. 1, b. 296, lap. 79.

" Lietuvos standartizacijos departamento technikos komiteto LST TK 47 ,Informacija ir dokumentavimas" susirinkimo protokolas Nr. 1, 2004, kovo mẻn. 25 d. [mašinraštis]. Vilnius, 2004. Lietuvos standartizacijos departamentas prie Lietuvos Respublikos aplinkos ministerijos. Ap. 1, b. 299, lap. 55.

14 Dèl technikos komiteto LST TK 47 veiklos pertvarkymo: Lietuvos standartizacijos departamento prie Lietuvos Respublikos aplinkos ministerijos direktoriaus $2004 \mathrm{~m}$. kovo $17 \mathrm{~d}$. jsakymas Nr. V-22 [mnšinrastis]. Vilnius, 2004, p. 2.

${ }^{13}$ Lietuvos standartizacijos departamento technjkos komiteto LST TK 47 ,Informacija ir dokumentavimas" nuostatai: patvirtinta Lietuvos standartizacijos departamento prie Lietuvos Respublikos aplinkos ministerijos direktoriaus $2004 \mathrm{~m}$. kovo $17 \mathrm{~d}$. jsakymu $\mathrm{Nr}$. V-22 [maSintaštis]. Vilnius, 2004, p. 6.

${ }^{16}$ Lietuvos standartizacijos departamento technikos komiteto LST TK 47 "Informacija ir dokumentavimas" ataskaitinio susirinkitmo protokolas Nr, 1, $2006 \mathrm{~m}$. kovo mèn. $6 \mathrm{~d}$. [masinuristis]. Vilnius, 2006. Lietuvos standartizacijos departamentas prie Lietuvos Respublikos aplinkos ministcrijos. Ap. 1, b. 309, lap. 12.

${ }^{17}$ Technikos komitetas LST TK 47 "Informacija ir dokumentavimas" : veiklos dešimtmetis. Vilnius, 2008, p. 6.

${ }^{18}$ Jusevičiūté, Valerija. Kinematografjjos kūriniai - Europos Sajungos saliụ nacionalinis audiovizualinis paveldas // Lietuvos standartizacijos biuletenis. -2008 , Nr. 11, p. 7-9.

${ }^{19}$ Lietuvos standartizacijos departamentas prje Lictuvos Respublikos aplinkos ministerjjos. [Vilnius], 2008. http://www.Isd.lvtypo_new/ [žiūrèta $2012 \mathrm{~m}$. sausio $26 \mathrm{~d}$.].

20 Technikos komitetas LST TK $47 \ldots$, p. 5.

\title{
Summary
}

\section{Standardized Integration for Memory Institutions: National Dimension}

\author{
Nijolè BLIŪDŽIUVIENĖ
}

Standardization in the context of Lithuanian memory institutions highlights experience and achievements against the background of the cultural and standardized integration. Analysis of activities and development of LST/TC 47 "Information and documentation" done on the basis of the investigation of the activities of the Technical Committee shows that reorganization of the Technical Committee resulted in the establishment of a very competent group of experts, which, in the absence of another institutional unit, could be considered as a representation of cross-sectoral partnership and significant standardization subject capable to cope with the multiple range of standards and specifics of different standardization activities, and applying its know-how for the processes of cultural and standardized integration of memory institutions. 